\title{
A Unique Friends of the Library Group
}

Mr. Schreiber is director, Administrative Services, Brandeis University Library.

$\mathrm{B}$ RANDEIS UNIVERSITY, located in Waltham, Massachusetts, is the only secular, non-sectarian institution of higher learning, sponsored by the Jewish people, in this country. It has the additional unique quality of being the only university whose library is completely supported by a Friends of the Library movement. The group is formally known as the National Women's Committee of Brandeis University. It has contributed over one million dollars to the development of the library in the past six years. The Women's Committee supports, and has supported the library from the day the university opened its doors. While six years is a short time in the life of a university, we have every reason to believe that it will continue as a thriving organization. As of June 30, 1954, there were over 44,000 members organized into 84 chapters around the country. In the belief that an organization of such size would be of interest to other librarians, I have prepared this report on the National Women's Committee.

When the Board of Trustees prepared to open Brandeis University in 1948, they were aware of the necessity of having a fine library for the university and of the costs involved. This awareness could hardly be avoided since Harvard was to be such a close neighbor, only a few miles away. The first venture was a "Books for Brandeis" campaign started by a few women, closely connected with the founders of the uni- versity, in the summer of 1948 , a few months before the opening of the school. This campaign met with indifferent success and was rather quickly cast into the mold which it has kept to the present day. Instead of trying to obtain books, the group obtained a charter as the Women's Committee of Brandeis University, and collected dues from its members, the funds going to the library. The sponsoring group believed that a large number of women, paying a low annual membership fee, might provide sufficient funds to enable the library to acquire the books needed by the students. It should be kept in mind that at this time, Brandeis was a university in name only. There were no graduate or professional schools. In fact, there was only a freshman class of 105, so for the first year at least not too many titles would be essential. The membership fee was set at five dollars and each potential member was told that this sum would purchase one book for the library, and that member's name would be inscribed on the bookplate inserted in the book. A chapter of the Women's Committee was set up in Boston, and very quickly a nucleus was formed in New York and Chicago. By the end of the first academic year, I I chapters with about 5,000 members had been established. It is probably unnecessary to state that benefactions larger than five dollars were received. Efforts were made to have individuals underwrite the costs of sets and other expensive items that are necessary for reference service as well as to the science instructors. By the end of the second year, the committee 
had grown to 16,000 members, in 48 chapters, and had included staff salaries and maintenance costs in its program. Since then, the National Women's Committee has been more than successful each year in providing the funds requested by the librarian.

This brief history of the organization poses many questions and answers none. The remainder of the paper will be devoted to some of the more obvious of these.

A new chapter is usually organized through personal contacts. When a few leaders in community activities become interested in Brandeis University, either through friends, or through our public relations program, they are offered whatever assistance they may desire from the university or from the national office of the Women's Committee, in getting a chapter started. This assistance includes printed material about the university, the library, and the functions of the Women's Committee. It includes speakers, who may be officers of the committee, members of the faculty, members of the university's administrative staff, the president of the university, members of the Board of Trustees, or the president of the board, and in some cases, notables who are not officially connected with the university, but who have offered their help. In brief, all the resources of the university may be drawn upon to help a group get started and to keep it functioning. Until the group has $50 \mathrm{mem}-$ bers, the membership is affiliated directly with the national body. New chapters are not chartered until they have a dues-paying membership exceeding that minimum figure. Once a group is functioning, they can, if they wish, arrange for speakers from the university faculty, who will not only discuss the university, but who will, if requested, lecture on the topics that concern them academically.

It may very well be asked, why the presi- dent of the university or of its board should take the trouble to travel around the country in assisting in the formation of such small groups? The immediate answer is that any president would be willing to devote a good deal of time and trouble to secure benefactions which exceed $\$ 250,000$ a year, and which are still rising. But as important as this direct benefit is, the indirect advantages are equally great. Through these chapters the university gains access to the men, the husbands, fathers, and relatives whose interest in the university may thus be stimulated.

The National Women's Committee has become an integral part of the university's fabric. To the best of my knowledge, no other similar group has been so closely drawn into the life of a university. The president of the Women's Committee is an ex-officio member of the Board of Trustees, and has as much voice as any other member of the board in the establishment of university policy. A member of the National Board of the Women's Committee sits in with the Faculty Library Committee and reports back on the discussions and decisions made at the meetings. Parenthetically, let it quickly be established that there has never been any vestige of interference with decisions of the Library Committee, or any attempt to exercise any control over book selection or the development of the library. The librarian and the comptroller discuss the budget of the library with a committee of the National Board before it is submitted to the Board of Trustees. All of these measures have been adopted to arm the Women's Committee with a complete picture of the operations of the library and of the university. Those chapters which are not too distant from the campus are urged to visit, to tour not only the library, but the entire campus. Displays of the newer media, such as microcards and microprint are arranged for them; they can watch the 
student body pursuing its normal life of study and recreation; and the latest developments and plans of the university are outlined to them by an officer of the university. We are currently producing a motion picture, concerning the university and the library, which will be used by those chapters too distant for such personal visits.

Every year, immediately after commencement, the Women's Committee holds a national conference on campus. Practically all the delegates arrive in time to participate, in one form or another, in the commencement activities. This conference lasts a week, during which the past year's activities of the library and the entire university are discussed with the delegates in detail. Panel discussions, by leading faculty members and visiting scholars, are held on the role of the liberal arts college, or similar topics. The theme of the conference in I954 revolved around intellectual freedom. This was explored as it related to the academic world, civilization as a whole, and obviously as it related to the American library picture. It is our belief, that the 300 delegates to the conference took back to their local chapters and to their 44,000 members an awareness of the current threats to intellectual freedom which may have general significance to the intellectual world. In addition there are numerous technical workshops, organized and conducted by the national headquarters, relating to increasing membership, obtaining additional funds, and similar matters. One session is usually devoted to a tour of the library, at which time every effort is made to bring home the need for and the functions of the various bits of equipment, especially the audio-visual material, which is strange to them, and to display the costlier reference and research sets and journal back files, with explanations of their use and importance. Another session is normally begun with an address from the librarian, which inevitably, regardless of the initial topic, turns into an explanation of the need for additional funds for the coming year, an analysis of accession and circulation statistics, and finally into a question-and-answer session in which we put on a bold front and indicate that it will probably be many decades before we rival any of the leading universities in terms of holdings.

This outline of activities would seem to give the impression that the entire activity of the university staff is given over to functions relating to this Friends movement and not to the legitimate affairs of a university. It is admitted that a good deal of time and effort is devoted to them. Nevertheless, if it is remembered that we have graduated only three classes, and that the sum total of our alumni has not yet reached 500 , it may be doubted that more time and energy is devoted to this group than a university normally devotes to the organization of its alumni groups. In addition, it should be pointed out that most of the work is done by the women and their own officers, who are volunteers. In any event, the university functions, and although the president and a few members of the staff are overburdened, the net result has been over $\$ 1,000,000$ and over 44,000 Friends, not only of the library, but of the university, and the leveling off is not yet in sight. Bluntly, it pays!

The most difficult question to which an answer must be attempted, is to what extent can other institutions profit by our experience? I have been unable to find sufficiently detailed accounts of other Friends groups to make comparisons of techniques. Superficially, however, it seems relatively certain that the intensity with which this organization has been cultivated at Brandeis is greater than most institutions have attempted. I believe also that this conscious striving for a mass membership with its low (Continued on page 369) 
College and university librarians have yet another advantage over school librarians. Most school libraries are small with only a few thousand volumes, while college libraries are much larger. Some are large institutions in their own right with hundreds of staff members. College library student assistants see much larger and more interesting and impressive libraries than do high school library student assistants. And they see full-time professional librarians giving good service, while high school students sometimes see a part-time librarian with little library education giving inadequate service. College students can see librarians in many different types of positions, while high school students see only one librarian, so they cannot appreciate the variety of jobs possible in the profession. All of this should make recruiting easier for the college librarian.
College librarians also work with students who are nearing maturity. They can guess more accurately how these students will turn out-how promising they arethan can high school librarians. They can predict with more accuracy how good these students would be as librarians.

College students are soon to be wageearners, so vocational choices are more important to them. High school students can postpone their decisions several years, but time is more pressing for college students. This should make them more serious, of course. Delivering the goods to library school should be easier when the students are only one instead of five years away.

College librarians, therefore, should be among our most successful recruiters; they have many advantages over other librarians. They must recruit in every library or our personnel shortage will continue.

\section{A Unique Friends of the Library Group}

\section{(Continued from page 367)}

annual dues-which is interpreted as "buying a book for Brandeis"-is new. Possibly we found ourselves in a position to take advantage of a pattern of community organization established and ingrained into the Jewish communities of the country by other Jewish philanthropies such as Hadassah, and such a pattern would not be generally available to other institutions. Very probably the unique quality of Brandeis as a non-sectarian university sponsored by the Jewish people triggered a wave of support and enthusiasm which would be difficult to generate for a university with generations behind it. If such is the case, the real test of our Friends movement will come when we have at least decades, if not generations, behind us. Nevertheless, for those librarians who have felt that their administrations are somewhat lukewarm in their support of their efforts to develop a Friends movement, it would seem as if this report could be of assistance as an indication of what may result trom a concerted and sustained effort which involves all elements of the university.

\section{Eastern College Conference}

The forty-first conference of the Eastern College Librarians will be held on Saturday, November 26, 1955, in McMillin Theater of Columbia University. The morning meeting will be devoted to "Recruiting Library Personnel" and the afternoon meeting to "Automation in the Library." A copy of the program will be mailed upon request to the chairman, Lorena A. Garloch, university librarian, University of Pittsburgh. 